\title{
Colgajo lateral de brazo en reconstrucción de la cavidad oral
}

\section{Lateral arm flap in oral cavity reconstruction}

\author{
A. Dean Ferrer', F.J. Alamillos Granados², J.J. Ruiz Masera3, A. Redondo Camacho 3 , J. Torres Corpas 3 , \\ G. Barrios Sánchez ${ }^{4}$ J.A. García de Marcos 5
}

Resumen: Introducción. La posibilidad de emplear una piel fácilmente plegable ha permitido reconstruir defectos de la cavidad oral consiguiendo una gran funcionalidad. Aunque el colgajo radial es el colgajo que se utiliza con más frecuencia para reconstruir defectos de superficie de la cavidad oral, el colgajo lateral de brazo puede ser de elección en algunas situaciones.

Objetivos. El objetivo del presente trabajo es mostrar las ventajas e inconvenientes y nuestras indicaciones y resultados del colgajo lateral de brazo en reconstrucción de defectos de la cavidad oral.

Material y método. Se trata de un estudio prospectivo sobre la utilización del colgajo lateral de brazo en la reconstrucción de defectos de la cavidad oral tras cirugía ablativa. Se ha valorado: la viabilidad del colgajo, la morbilidad del lecho donante, la longitud del pedículo, la selección de vasos receptores, las complicaciones y los resultados funcionales de la zona reconstruida. Resultados. Hemos utilizado el colgajo lateral de brazo en 10 pacientes en reconstrucciones primarias tras cirugía ablativa por carcinoma epidermoide de la cavidad oral. Hubo un caso de necrosis por trombosis venosa. El defecto donante se cerró en 8 casos de modo directo y en 2 con un injerto libre de espesor parcial. La longitud media del pedículo ha sido de $8,75 \mathrm{~cm}$. En 9 casos el resultado funcional de los pacientes ha sido satisfactorio.

Conclusiones. El colgajo fasciocutáneo lateral de brazo permite la reconstrucción de la cavidad oral consiguiendo buenos resultados funcionales. Además la morbilidad de la zona donante es mínima y puede realizarse cierre directo del defecto cutáneo del brazo en la mayoría de los casos.

Palabras clave: Colgajos libres; Defectos de cavidad oral; Reconstrucción oral; Colgajo libre lateral de brazo; Colgajo libre antebraquial.

Recibido: 27.12 .05

Aceptado: 28.04 .08

1 Jefe de Sección. Hospital Universitario "Reina Sofía". Córdoba. Fellow of the European Board of Oral and Maxillofacial Surgery. Profesor asociado de la Facultad de Medicina. Universidad de Córdoba. España.

2 Facultativo Especialista de Área. Hospital Universitario "Reina Sofía". Córdoba. Fellow of the European Board of Oral and Maxillofacial Surgery. Profesor asociado de la Facultad de Medicina. Universidad de Córdoba. España.

3 Facultativo Especialista de Área. Hospital Universitario "Reina Sofía". Córdoba.

4 Especialista en Cirugía Oral y Maxilofacial. Práctica privada.

5 Médico Residente. Servicio de Cirugía Oral y Maxilofacial. Hospital Universitario "Reina Sofía". Córdoba. España

Correspondencia:

Dra. Alicia Dean

C/ losé Ma Martorell 4, $2^{\circ}-2$

14005 Córdoba. España

Email: ADF10101@teleline.es
Abstract: Introduction. The availability of easily pliable skin has allowed the functional reconstruction of oral cavity defects. Although the radial forearm free flap is the most frequently used flap for the reconstruction of surface defects of the oral cavity, the lateral arm free flap may be preferable in some situations.

Objectives. The aim of the present paper is to show the advantages and disadvantages and our indications and results for the lateral arm flap in intraoral reconstruction.

Material and methods. This is a prospective work on the use of the lateral arm free flap for the reconstruction of oral cavity defects after ablative surgery. The parameters that have been evaluated are: flap viability, morbidity in the donor site, length of the pedicle, selection of recipient vessels, complications and functional results in the reconstructed area.

Results. The lateral arm flap has been used in primary reconstruction after ablative surgery for squamous cell carcinoma of the oral cavity in ten patients. One flap was lost because of venous thrombosis. The donor site was repaired by direct closure in 8 cases and a split thickness skin graft had to be used in 2 cases. Mean pedicle length was $8.75 \mathrm{~cm}$. In 9 cases a favorable functional result was achieved. Conclusions. Fasciocutaneous lateral arm flap allows the reconstruction of oral cavity defects achieving good functional results. Morbidity in the donor site is minimal and, in most cases, direct closure permits the repair of the donor site.

Key words: Free flaps; Oral cavity defects; Oral cavity reconstruction; Lateral arm free flap; Radial free flap. 


\section{Introducción}

El colgajo lateral de brazo es un colgajo muy versátil y ampliamente utilizado en defectos postraumáticos de extremidades superiores pero muy poco utilizado en reconstrucción de cabeza y cueIlo. Este colgajo fue descrito por primera vez por Song en 1982. ${ }^{1}$ Sin embargo, su aplicación en cabeza y cuello no se extendió de forma significativa hasta 1992, con Sullivan y Cols. ${ }^{2}$ Desde entonces, numerosos trabajos han ampliado las posibles aplicaciones de este colgajo a nivel oro-c'Ervico-facial.

Se trata de un colgajo que transfiere tejidos similares a los del colgajo radial pero a diferencia de éste y como principal ventaja, está basado en un pedículo que no es esencial para la vascularización de la extremidad distal del miembro superior.3,4 Es un colgajo fasciocutáneo que recibe su aporte vascular de una rama terminal de la arteria braquial profunda, la arteria radial colateral posterior, que se localiza en el septum intermuscular lateral del brazo. ${ }^{2,5}$

Los objetivos del presente trabajo son:

1. Mostrar las indicaciones, ventajas e inconvenientes y nuestras indicaciones y resultados en reconstrucción de defectos de la cavidad oral con colgajo lateral de brazo.

2. Revisar la técnica quirúrgica de elevación del colgajo realizando una descripción anatómica y presentando los refinamientos.

\section{Material y método}

Se ha realizado la reconstrucción de defectos de cavidad oral mediante colgajo libre lateral de brazo en 10 pacientes. En todos ellos ha sido una reconstrucción primaria tras cirugía ablativa de carcinoma epidermoide de cavidad oral. La localización y características de los casos quedan recogidas en la tabla 1 . Se han valorado la edad y sexo de los pacientes, la localización del tumor primario, el tipo de vaciamiento cervical, el tamaño de la isla cutánea, la longitud del pedículo, la selección de los vasos receptores, el cierre del defecto del brazo, viabilidad del colgajo y posibles complicaciones, los resultados funcionales y la necesidad de cirugías secundarias.

\section{Anatomía y técnica quirúrgica}

El brazo está dividido por unos septos intermusculares en un compartimento extensor y un compartimento flexor. El pedículo vascular del colgajo lateral del brazo es la rama colateral radial posterior de la arteria braquial profunda que procede de la arteria braquial. A nivel del tercio distal del húmero, la arteria braquial profunda se bifurca en una rama colateral anterior y otra posterior. La arteria radial colateral posterior (ARCP) se localiza en el septum intermuscular lateral entre el músculo triceps posteriormente y el músculo braquioradial anteriormente y aporta vascularización a la parte lateral del brazo. Esta rama acompaña al nervio radial en el surco espiral del húmero (Fig. 1). El calibre medio de la arteria es de 1,5-2 mm 2,5,6 y de 2 y 3 mm el de las venas.5,6 La longitud media del pedículo es de 6-8 cm, pero puede ampliarse $2-3 \mathrm{~cm}$ más, disecando la arteria braquial profunda en el surco espiral después de separar el deltoides y el triceps o desinsertando el tendón de la cabeza lateral del triceps. 2,3,7-9

\section{Introduction}

The lateral arm flap is a flap that is very versatile and used widely in post-traumatic defects of the upper extremities, but it is not very often used in reconstructions of the head and neck. This flap was first described by Song in 1982. ${ }^{1}$ However, it was not significantly applied in the head and neck until 1992, when Sullivan y Cols. ${ }^{2}$ used it. Since then, as a result of numerous works, the possibilities of using this flap at an oro-cervical-facial level have increased.

This flap has similar tissue to that of the radial flap, but it differs in that it has the great advantage of a pedicle that is not essential for the vascularization of the distal extremity of the upper limb. 3,4 It is a fasciocutaneous flap that receives its vascular supply from a terminal branch of the deep brachial artery, the posterior radial collateral artery, which is located in the lateral intermuscular septum of the arm. ${ }^{2,5}$

The objectives of this paper are:

1. To show the indications, advantages and disadvantages and our indications and results in the reconstruction of defects of the oral cavity with a lateral arm flap.

2. To revise the surgical technique for harvesting the flap, giving an anatomical description and presenting the refinements.

\section{Material and methods}

The reconstruction of defects of the oral cavity was carried out in ten patients using a lateral arm free flap. In all cases primary reconstruction was carried out following ablative surgery for squamous cell carcinoma of the oral cavity. The location and characteristics of these cases are reflected in table 1. The age and sex of the patients was taken into consideration together with the location of the primary tumor, the type of neck dissection, the size of the cutaneous island, length of the pedicle, selection of the receptor vessels, closure of the arm defect, viability of the flap, possible complications, functional results and the need for secondary surgery.

Anatomy and technical surgery

The arm is divided by the intermuscular septum into extensor and flexor compartments. The vascular pedicle of the lateral arm flap is the posterior radial collateral branch of the deep brachial artery that runs from the brachial artery. By the distal third of the humerus, the deep brachial artery divides into an anterior collateral branch and another posterior branch. The posterior radial collateral artery (PRCA) is located in the lateral intermuscular septum between the triceps muscle posteriorly, and the brachioradial muscle anteriorly, and it provides vascularization to the lateral part of the arm. The radial nerve runs together with this branch to the spiral groove of the humerus (Fig. 1). The average caliber of the artery is 1.5 to $2 \mathrm{~mm}^{2,5,6}$ and the average caliber of the vein is 2 to $3 \mathrm{~mm} .5,6$ The average length of the pedi- 


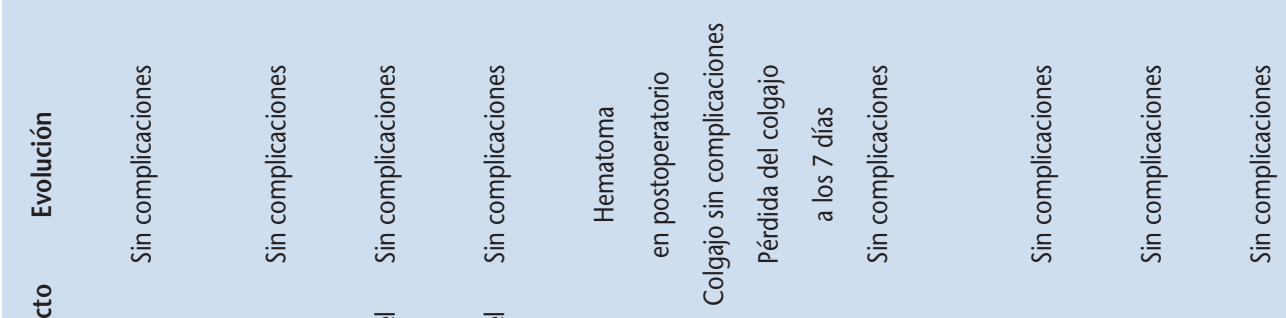

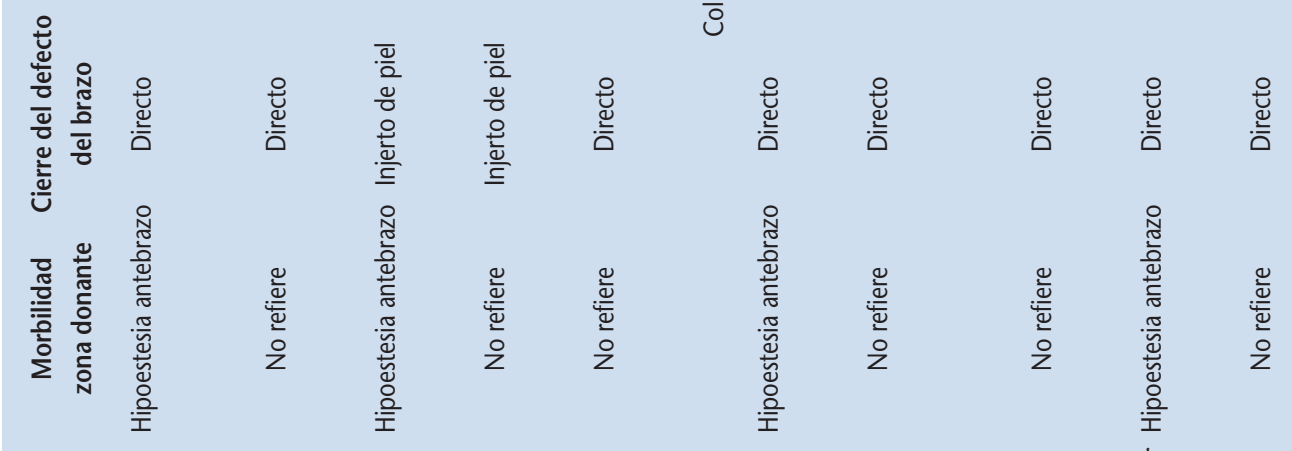

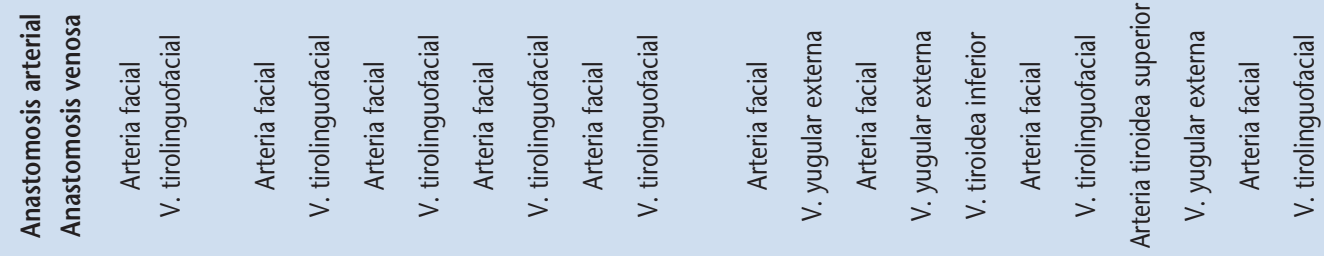

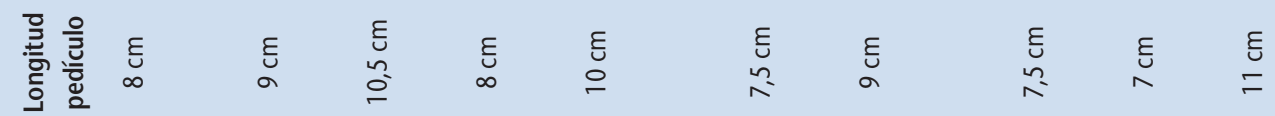

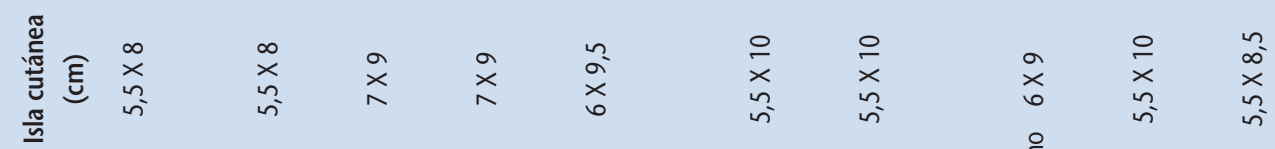

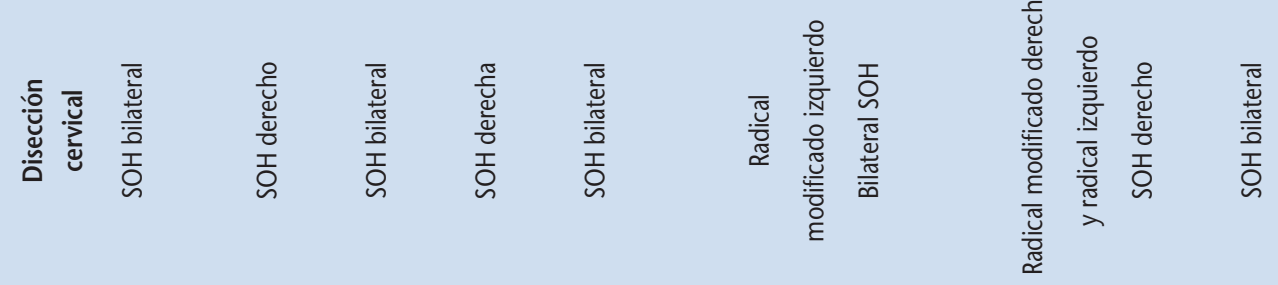

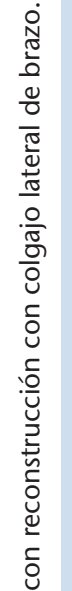

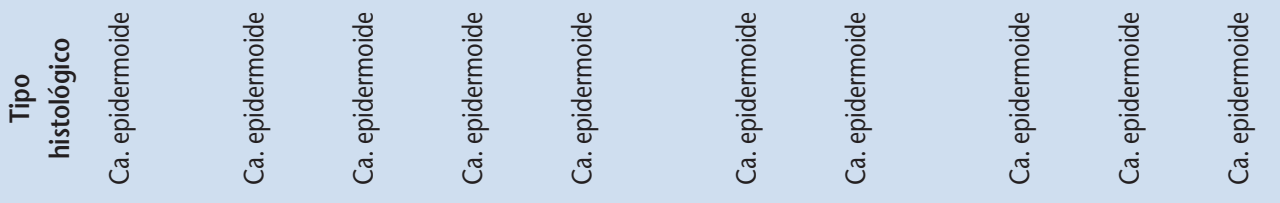

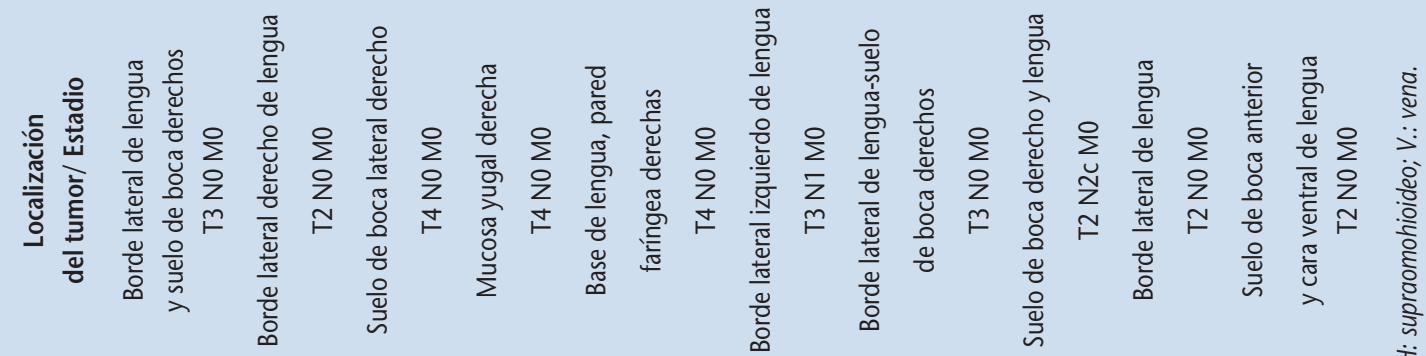

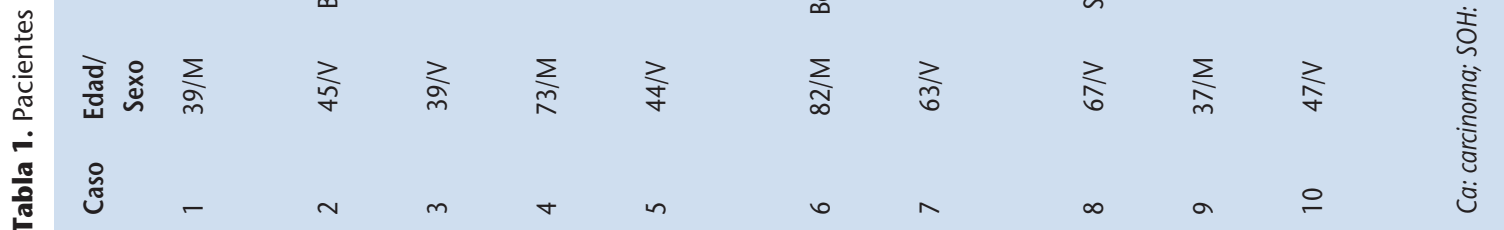




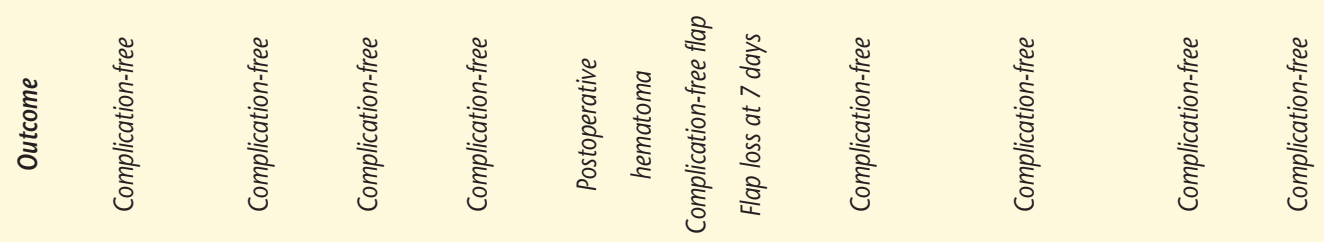

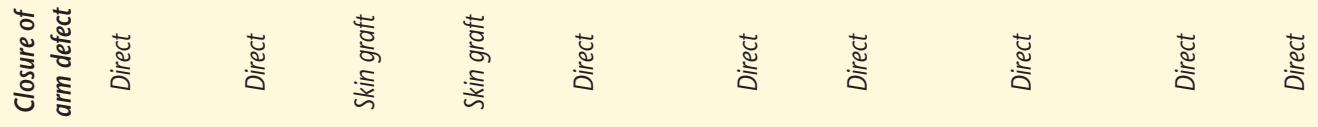

$\|+1=1+1=$

$\| n||||||||||||||||$

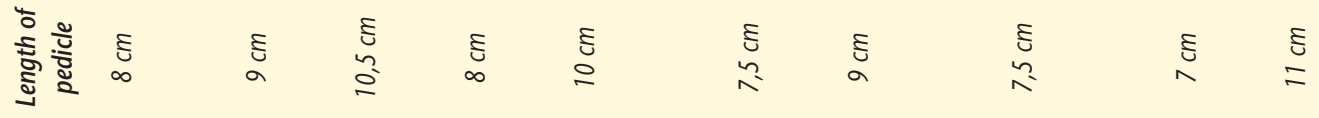

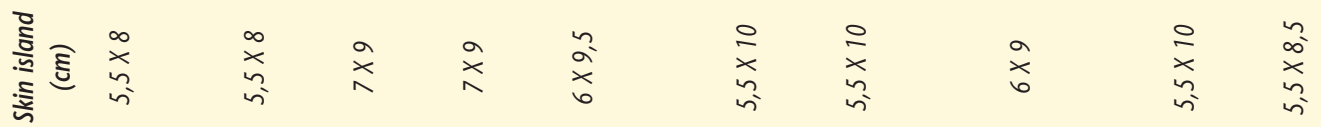

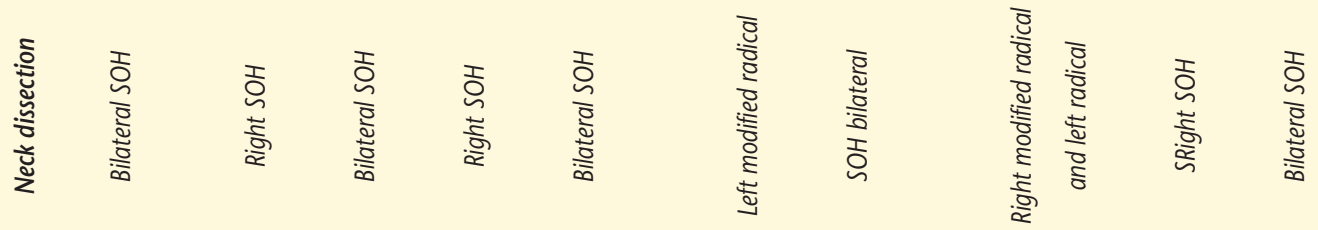

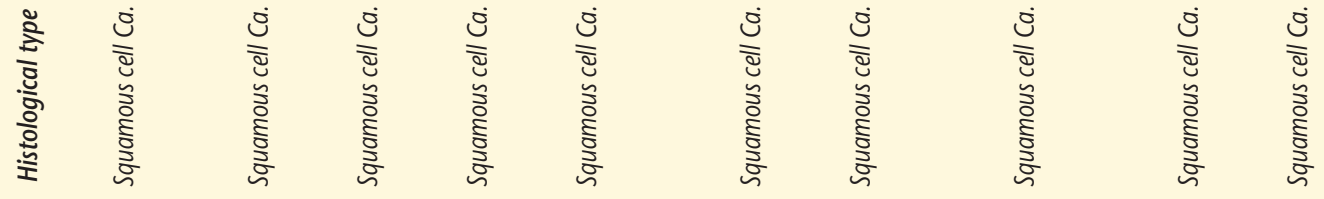

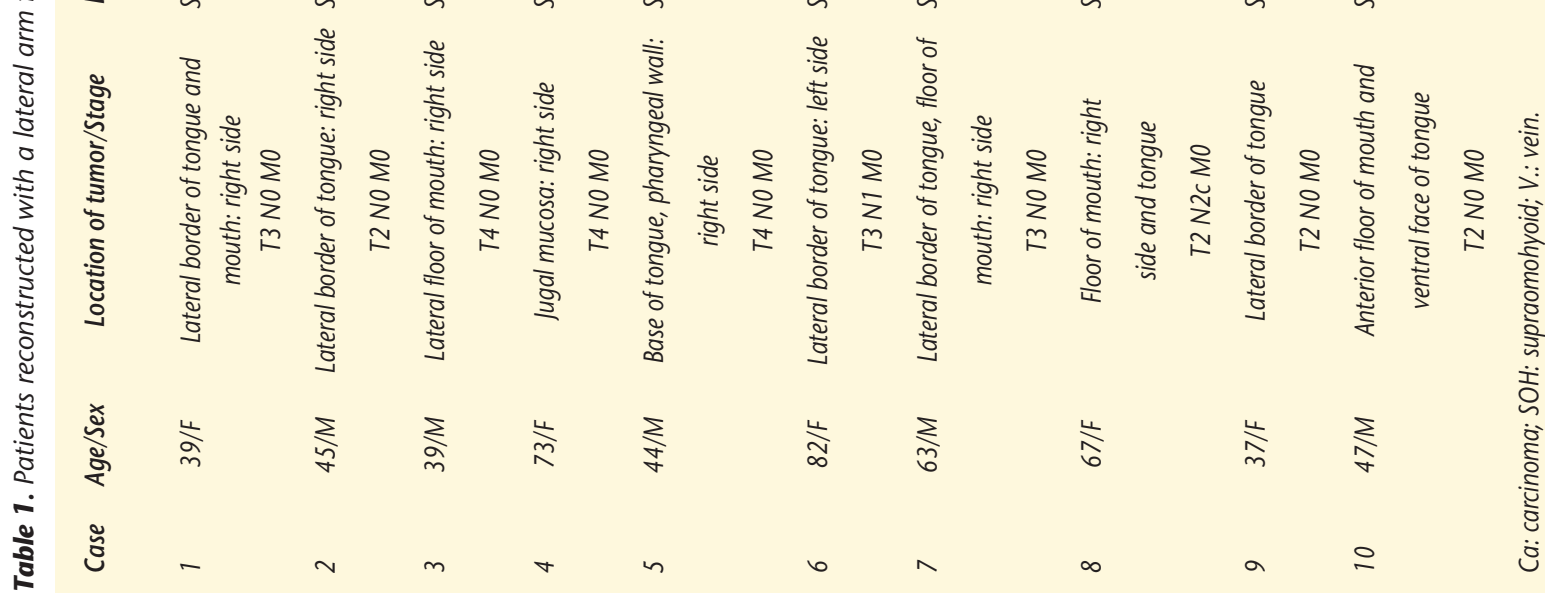


La ARCP da entre cuatro a siete ramas perforantes que ascienden en el septum intermuscular lateral y se localizan entre $1 \mathrm{~cm}$ y $15 \mathrm{~cm}$ por encima del epicóndilo. ${ }^{7}$ La mayor de ellas o dominante se localiza a unos $10 \mathrm{~cm}$ proximal al epicóndilo del brazo. 7 Las variaciones anatómicas son raras. Se han descrito casos de dos ARCP paralelas que aportaban vascularización al colgajo y la anastomosis de sólo una de ellas fue suficiente para la correcta perfusión de la piel. 2,7,10 El pedículo da ramas para la vascularización del húmero, de la fascia intermuscular, del tejido subcutáneo y de la piel. El nervio que da sensibilidad a la piel del colgajo es el nervio cutáneo posterior del brazo y puede elevarse como colgajo neurotizado para anastomosarlo a un nervio sensitivo del lecho receptor. Puede transferirse también el nervio cutáneo posterior del antebrazo como nervio vascularizado si fuera necesario.

El colgajo lateral del brazo puede tener dos sistemas venosos de drenaje: el superficial y el profundo. El sistema profundo está formado por las venas concomitantes que acompañan a la ARCP y pueden fusionarse para formar un solo vaso a nivel del surco espiral del húmero. ${ }^{2}$ El sistema venoso superficial está compuesto por venas del plexo subcutáneo que drenan en la vena cefálica. Ambos sistemas son suficientes para el drenaje de este colgajo por sí solo, aunque nosotros hemos utilizado siempre el sistema concomitante a la ARCP.

El colgajo lateral de brazo puede elevarse en posición supina del paciente al mismo tiempo que se realiza la ablación. En las personas mayores, debido a la flaccidez de los tejidos dermoepidérmicos, hay que tener precaución a la hora de diseñar la isla cutánea pues podría verse desplazada respecto al septum intermuscular. El colgajo puede elevarse con o sin torniquete. Nosotros utilizamos torniquete pediátrico porque el de adultos, debido a su mayor anchura dificulta la elevación de la parte más superior del colgajo. Si fuera necesario prolongar la longitud del pedículo puede retirarse el torniquete en ese momento y proseguir la disección sin torniquete.

El eje vascular del colgajo se localiza $1 \mathrm{~cm}$ dorsal a una línea que une el epicóndilo del codo con la inserción del deltoides. La cantidad de piel que puede irrigar la ARCP según estudios de inyección es de unos $8 \times 10 \mathrm{~cm}$ a $14 \times 15 \mathrm{~cm} .5,11,12$ La mayoría de los autores recomiendan limitar la anchura del colgajo a $6-7 \mathrm{~cm}$ para permitir el cierre directo del defecto. ${ }^{10,11,13}$ Nosotros, al igual que Sullivan valoramos la posibilidad del cierre directo en el preoperatorio mediante "pellizcado" del pliegue de piel en la zona del colgajo.

La disección de la isla cutánea puede comenzarse en la parte anterior o en la posterior. Se inciden la piel, el tejido celular subcutáneo y la fascia muscular subyacente que se incluyen en el colgajo. La disección prosigue subfascial hasta llegar al septum intermuscular por la cara anterior y la posterior, llegando en profun- cle is $6-8 \mathrm{~cm}$, but this can be increased by another 2-3 $\mathrm{cm}$, by dissecting the deep brachial artery by the spiral groove after separating the deltoid and the triceps, or by separating the tendon from the lateral head of the triceps. $2,3,7-9$

The PRCA gives off four to seven perforating branches that ascend to the lateral intermuscular septum and they are to be found between $1 \mathrm{~cm}$ and $15 \mathrm{~cm}$ above the epicondyle.? The larger of these, or the dominant one, is found some 10 $\mathrm{cm}$ proximal to the epicondyle of the arm. ${ }^{7}$ Anatomical variations are rare. Cases of two parallel PRCA have been described that provided the flap with vascularization, and the anastomosis of just one of them was enough to achieve the correct skin perfusion. 2,7,10 The pedicle provides branches for the vascularization of the humerus, the intermuscular fascia, the subcutaneous tissue and skin. The nerve that provides sensitivity to the skin of the flap is the posterior cutaneous nerve of the arm, and it can be harvested as a neurotized flap. It can be anastomosed to a sensory nerve of the receptor bed. Should it be necessary, the forearm posterior cutaneous nerve can be transferred as a vascularized nerve.

The lateral arm flap can have two venous systems for drainage: the superficial and deep systems. The deep system is formed by concomitant veins that accompany the PRCA that can join to form just one vessel by the spiral groove of the humerus. ${ }^{2}$ The superficial venous system is made up of veins in the subcutaneous plexus that drain into the cephalic vein. Both systems are enough for draining this flap, although we have always used the concomitant system of the PRCA.

The lateral arm free flap can be raised with the patient in a supine position while the ablation is carried out. In older people, due to the flaccidity of dermoepidermic tissues, care has to be taken on designing the cutaneous island, as this could be displaced with regard to the intermuscular septum. The flap can be raised with or without a tourniquet. We use a pediatric tourniquet because the adult one, as it is wider, makes raising the uppermost part of the flap difficult. If extending the length of the pedicle were necessary, the tourniquet can be removed at this point and the dissection can be continued without a tourniquet.

The vascular axis of the flap is found $1 \mathrm{~cm}$ dorsal to the line joining the epicondyle and the elbow with the deltoid insertion. The amount of skin that the PRCA can irrigate according to injection studies is of some $8 \times 10 \mathrm{~cm}$ to $14 \times 15 \mathrm{~cm} .5,11,12$ 
didad hasta su inserción en el húmero. En la cara anterior del septum, el músculo braquioradial tiene inserciones musculares en éste, por lo que la disección debe ser muy cuidadosa para no lesionar los vasos del pedículo. En la parte posterior el triceps no tiene inserciones musculares en el septum por lo que la disección es más fácil. Los vasos del pedículo se localizan en la parte más profunda del septum, muy próximos al húmero. El septum se secciona distalmente y se ligan las extensiones distales del pedículo. El nervio radial debe preservarse y separarse del septum intermuscular una vez que se han identificado los vasos radiales colaterales posteriores. Si se realiza una extensión superior de la incisión cutánea a lo largo del borde posterior del deltoides se permite una disección del pedículo hacia arriba en el surco espiral del humero. La disección del pedículo en el surco espiral aumenta la longitud de éste en unos 2 a $3 \mathrm{~cm}$.

El cierre del defecto puede realizarse de modo directo o bien mediante la utilización de un injerto de piel. Se aconseja dejar un drenaje en el lecho quirúrgico. No es necesario ferulizar el brazo.

Caso 9: Mujer de 37 años de edad que presentaba carcinoma epidermoide de borde lateral de lengua. T2 N0 M0. Se realizó vaciamiento cervical supraomohioideo derecho, glosectomía parcial y reconstrucción del defecto lengua mediante colgajo lateral de brazo izquierdo. Posteriormente fue sometida a tratamiento radioterápico (Figs. 2 a 5).

\section{Resultados}

Los resultados de todos los parámetros analizados quedan recogidos en la tabla 1.

En 9 casos el resultado funcional de los pacientes ha sido satisfactorio. Solo en un paciente con defecto de la cara ventral fue necesario realizar cirugía secundaria de adelgazamiento del colgajo ya que el abombamiento del colgajo dificultaba la adecuada movilidad de la lengua remanente. En el resto de los pacientes no ha sido necesario hacer cirugías secundarias.

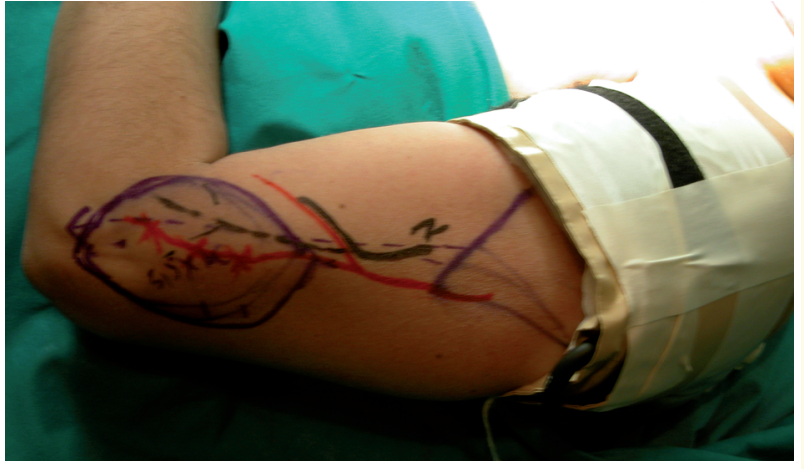

Figura 2. Diseño del colgajo lateral del brazo para reconstrucción de un defecto tras ablación de un carcinoma epidermoide de borde lateral de lengua. Se aprecia manguito pediátrico en posición.

Figure 2. Design of the lateral arm flap for reconstructing a defect following ablation due to squamous cell carcinoma of the lateral border of the tongue. The pediatric tourniquet can be seen in position.

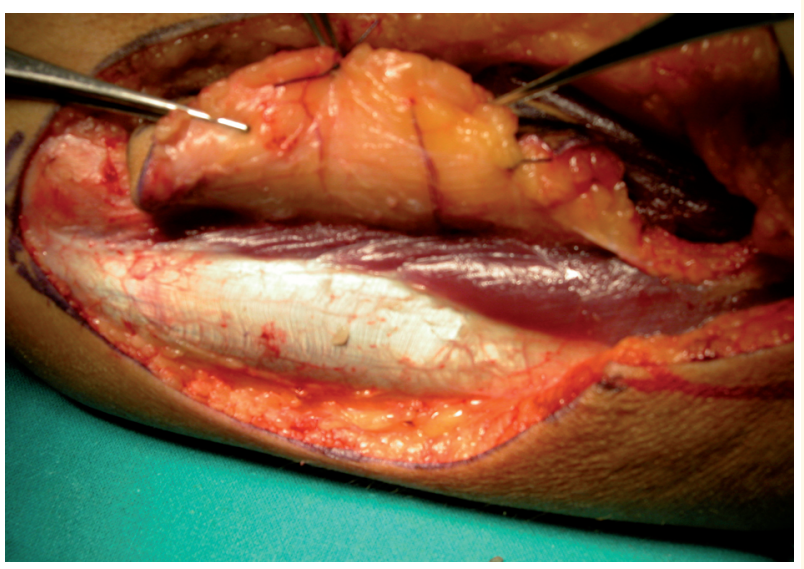

Figura 3. Cara posterior del septum del colgajo donde se aprecian las perforantes.

Figure 3. Posterior side of the septum of the flap showing the perforating branches.

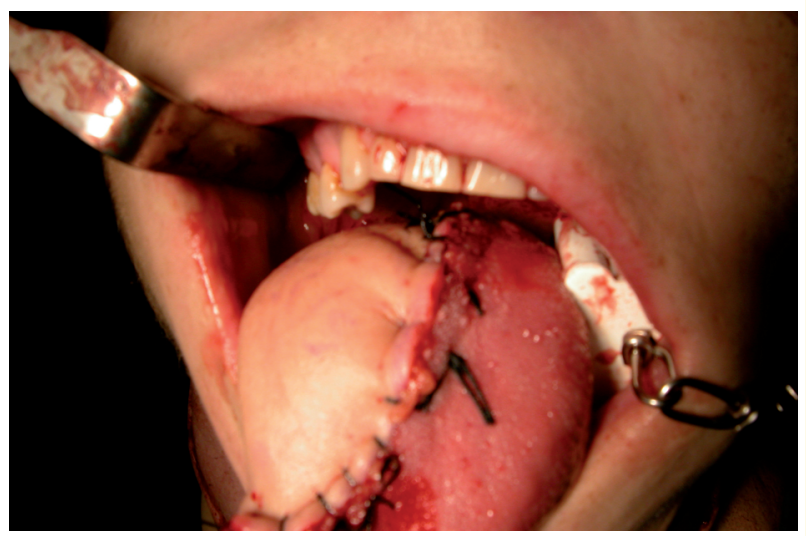

Figura 4. Aspecto intraoperatorio de la reconstrucción lingual. Figure 4. Intraoperative appearance of the lingual reconstruction.
Most authors recommend limiting the width of the flap to 6-7 $\mathrm{cm}$ to allow direct closure of the defect. 10,11,13 Like Sullivan, we favor the possibility of direct closure by means of "pinching" the skin fold in the area of the flap.

The dissection of the skin island can be started in the anterior or posterior part. The skin, subcutaneous cellular tissue and underlying muscle fascia that are to be included in the flap are incised. The dissection continues in a subfascial sense until the intermuscular septum is reached via the anterior and posterior faces, and until the insertion of the humerus is reached. The brachioradial muscle has muscular insertions in the anterior face of the septum, and the dissection has to be carried out very carefully in order not to damage the vessels of the pedicle. In the posterior part, the triceps does not have muscular insertions into the septum and the dissection is easier. The vessels of the pedicle are found in the deeper part of the septum, very near the humerus. The septum is sectioned distally and the extensions are ligated distal to the pedicle. The radial nerve should be preserved and separated from the intermuscular septum once the posterior radial collateral vessels have been identified. If a superior extension of the cutaneous incision is carried out along the posterior border of the deltoid, the pedicle can be dissected upwards to the spiral groove of the humerus. The dissection of the pedicle by the spiral groove increases its length by 2 to $3 \mathrm{~cm}$.

Closure of the defect can be carried out directly or by means of a skin graft. Leaving drainage in the surgical bed 


\section{Discusión}

La posibilidad de emplear una piel fácilmente plegable y adaptable a los contornos de la cavidad oral ha permitido reparar defectos de la mucosa de la cavidad oral consiguiendo una gran funcionalidad. Si el tejido aportado para reconstruir un defecto oral no es plegable y adaptable a los contornos y no permite la movilidad de la lengua residual, cumplirá las funciones de cobertura y cierre de la cavidad oral, pero limitará la función deglutoria y fonatoria. El colgajo fasciocutáneo radial ha sido ampliamente utilizado para recubrimiento de defectos de superficie de la cavidad oral por su alta fiabilidad y sencillez técnica. Sin embargo, la delgadez de este colgajo hacen que en ocasiones el volumen del tejido aportado sea inferior al deseado. ${ }^{6}$ Además hay pacientes con test de Allen negativo o que no aceptan las secuelas estéticas de la zona donante que junto con la morbilidad del lecho donante del colgajo radial inherente a su utilización y a la supresión de una arteria importante en la vascularización de la mano, hacen que deba considerarse el colgajo lateral de brazo como opción reconstructiva válida en ciertos casos.6,14 Una de las ventajas del colgajo lateral de brazo respecto al colgajo radial es que utiliza un sistema vascular que no es esencial para la vascularización de brazo. 3,6

En cuanto al sistema venoso del colgajo lateral de brazo, algunos autores utilizan el sistema venoso de la vena cefálica en vez del sistema concomitante. ${ }^{10}$ En los casos presentados hemos utilizado siempre el sistema venoso concomitante. Puede elevarse el colgajo con los dos sistemas venosos y utilizar el cefálico en el caso de el sistema profundo no sea adecuado. En ausencia de vasos venosos receptores en cabeza y cueIlo, puede movilizarse la vena cefálica hasta la vena subclavia sin perder la continuidad en ningún momento, realizando la anastomosis arterial en el cuello. ${ }^{15}$

El colgajo puede elevarse sin piel, como colgajo fascial si se precisa menor volumen o si no se desea piel en la reconstrucción (para aumentos de volumen en reconstrucción del contorno facial). $2,4,5,11$ Hay estudios de inyección que demuestran también que una parte del húmero de unos $10 \times 1 \mathrm{~cm}$ está vascularizada por ramas periósticas de la ARCP pudiéndose elevar un colgajo osteofasciocutáneo. ${ }^{11}$ El septum puede dividirse manteniendo la continuidad de las perforantes con lo que obtiene un colgajo con islas de tejido con su

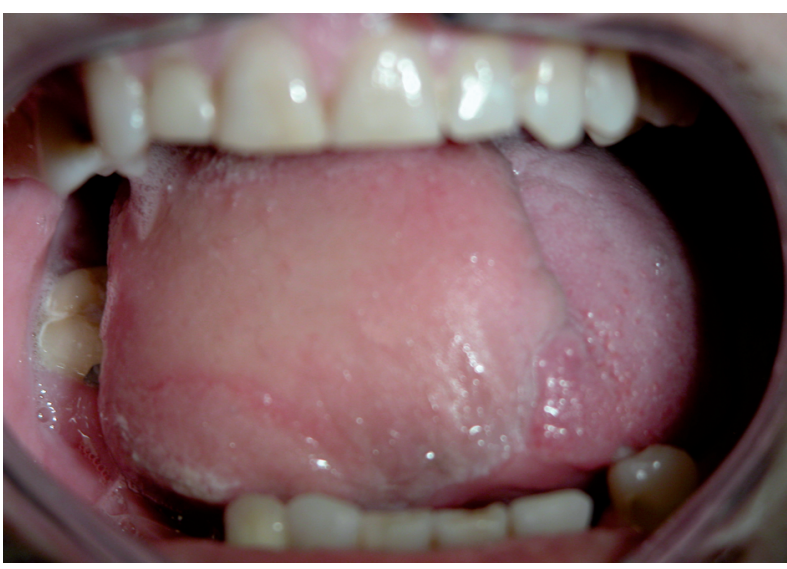

Figura 5. Aspecto de la reconstrucción lingual a largo plazo. Figure 5. Long-term appearance of the lingual reconstruction.

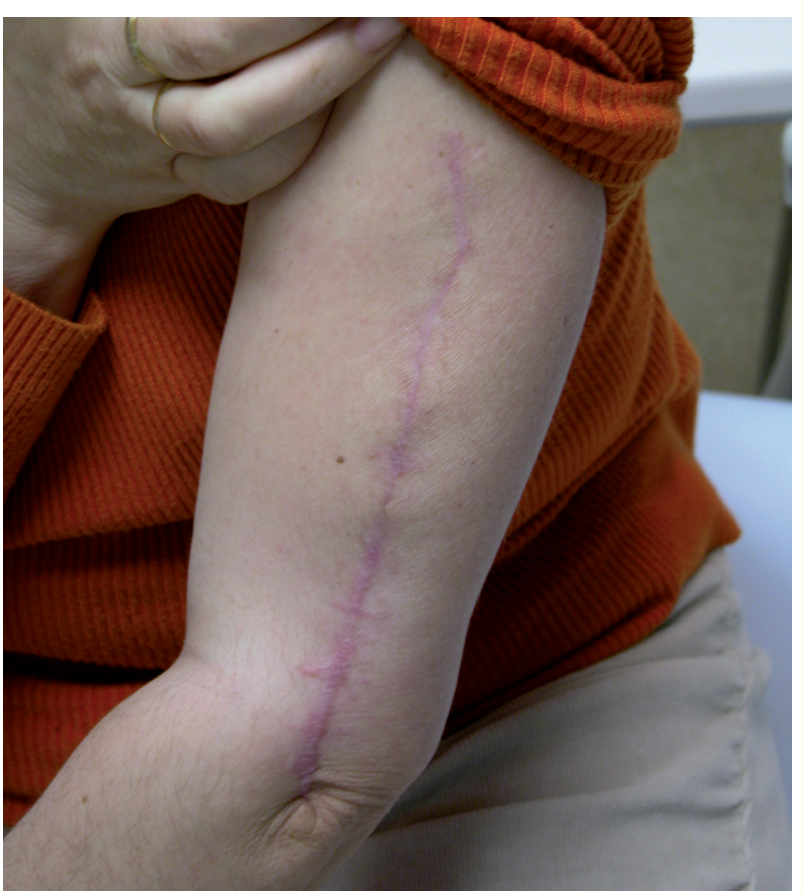

Figura 6. Zona donante.

Figure 6. Donor site. is advisable. The arm does not require a splint.

Case 9: Female, 37 years old, with squamous cell carcinoma of the lateral border of the tongue. T2 NO MO. Right supraomohyoid neck dissection was carried out together with a partial glossectomy and reconstruction of the tongue defect by means of a lateral left arm flap. She later underwent radiotherapy treatment (Figs. 2,3,4 and 5).

\section{Results}

The results of all the parameters analyzed are reflected in table 1.

In nine cases the functional result for the patients was satisfactory. Only one patient with a defect in the ventral face of the flap required secondary surgery to reduce the flap as the bulge made moving the remaining tongue difficult. The remaining patients did not require secondary surgery.

\section{Discussion}

The possibility of using skin that is easily pliable and that adapts to the shape of the oral cavity has permitted repairing defects of the oral cavity mucosa and achieving very good functional results. If the tissue obtained for reconstructing an oral defect is not pliable, and if it does not adapt to the contours, and if the remaining tongue cannot be moved, it will meet the requirements as to covering and closing the oral cavity, but swallowing and speech will be limited. The fasciocutaneous radial flap has been widely used for covering surface defects of the oral cavity as it is very reliable and the technique is simple. However, the thinness of this flap means that on occasions the volume of tissue obtained is less than what is required. 6 The lateral arm flap should be considered as an option in reconstructions as it is valid in certain cases. There 
propia rama vascular fascial y un solo pedículo. ${ }^{7}$ El colgajo puede extenderse hacia la piel del antebrazo (colgajo lateral de brazo-proximal del antebrazo), ${ }^{16}$ consiguiendo mayor longitud de pedículo y mayor superficie de piel.

El colgajo lateral de brazo es más fino en la parte distal y se va engrosando progresivamente. Esto se debe tener en consideración a la hora de adaptarlo al defecto quirúrgico y puede ser una ventaja para ciertos tipos de defectos orofaríngeos. ${ }^{14,17}$ La porción más fina puede utilizarse para la pared faríngea y la porción más gruesa para la base de la lengua. El colgajo lateral de brazo tiene mayor grosor que el colgajo libre radial, pero sigue siendo un colgajo fino adecuado para adaptarse a los contornos orales. Cuando es necesario añadir más volumen puede elevarse el colgajo lateral de brazo con una porción de músculo triceps. 18,19

La sección del nervio cutáneo posterior del antebrazo, que se produce en la mayoría de los casos durante la elevación del colgajo, produce un déficit sensitivo en la cara extensora del antebrazo que normalmente no es apreciado por el paciente y que disminuye con el tiempo. ${ }^{2}$

Hay varias formas de conseguir mayor longitud del pedículo: siguiendo su disección proximalmente como se ha descrito en la técnica quirúrgica con desinserción del triceps ó colocando la isla de piel más distalmente. ${ }^{14}$

El cierre del defecto del colgajo lateral de brazo puede realizarse casi siempre de forma directa (si la anchura del defecto es menor o igual a $6 \mathrm{~cm}$ ). En nuestro caso se injertaron 2 de los pacientes. El defecto estético es menor con el colgajo lateral de brazo comparado con el colgajo radial. ${ }^{3}$ La morbilidad asociada a la zona donante del colgajo lateral es escasa, aunque se han descrito: dolor en epicóndilo, hipoestesia de la piel proximal del antebrazo y disminución de la capacidad de movimiento del codo. ${ }^{20}$

El colgajo puede elevarse por un segundo equipo quirúrgico de forma simultánea al equipo ablativo. ${ }^{5} \mathrm{El}$ examen preoperatorio consiste sólo en una exploración de la zona donante. Los vasos del cuello que mejor se adaptan al calibre de los vasos del colgajo son la arteria tiroidea superior y la arteria facial y venas del tronco tirolinguofacial. ${ }^{5}$

La fiabilidad de este colgajo es similar a la de cualquier otro utilizado en la reconstrucción de cabeza y cuello, situándose en general en el $95 \% .4,6,14,17$

El colgajo lateral de brazo debe considerarse como opción reconstructiva de defectos de superficie mucosa oral. Las ventajas de este colgajo son: aporta cobertura fina, plegable y adaptable a los contornos de la cavidad oral consiguiendo buenos resultados funcionales en defectos de superficie; posee un pedículo vascular constante, que además no es esencial para la vascularización de la extremidad distal del miembro superior; puede elevarse como colgajo neurotizado; es rápido y fácil de elevar; puede elevarse a la vez que se realiza la ablación, no hay que cambiar de postura al paciente; aporta un grosor intermedio por ello, es útil para defectos de cavidad oral en los que se requiera aportar más volumen que el que aporta el colgajo radial; la morbilidad de la zona donante es escasa; puede realizarse cierre directo del defecto cutáneo en muchos de los casos consiguiendo un resultado estético de la zona donante muy aceptable y aunque el pedículo es corto, existen técnicas quirúrgicas para alargarlo. are patients with negative Allen's tests, and others that do not accept the aesthetic sequelae in the donor site, and there is the morbidity of the donor bed of the radial flap inherent to its use, and the suppression of an important artery in the vascularization of the hand 6,14 One of the advantages of the lateral arm flap with regard to the radial flap is that it uses a vascular system that is not essential for the vascularization of the arm.3,6

With regard to the venous system of the lateral arm flap, some authors use the venous system of the cephalic vein in stead of the concomitant system..$^{10}$ In the cases presented, we have always used the concomitant venous system. The flap can be harvested with both venous systems, and the cephalic system can be used should the deep system not be adequate. If there is an absence of receptor venous vessels in the head and neck, the cephalic vein can be moved to the subclavian vein and continuity is not lost at any moment, and arterial anastomosis is carried out in the neck. ${ }^{15}$

The flap can be harvested without skin, as a fascial flap, if less volume is needed or if skin is not required in the reconstruction (when increasing volume in facial contour reconstruction).2, $4,5,11$ There are in addition injection studies that show how there is an area of humerus measuring $10 \times 1 \mathrm{~cm}$ that is vascularized by periosteal branches of the PRCA, and that an osteofasciocutaneous flap can be harvested. "1 The septum can be divided and the continuity of the perforating branches can be maintained. A flap with tissue islands, fascia with its own vascular branch, and with a single pedicle can be obtained. The flap can be extended towards the skin of the forearm (Lateral arm/proximal forearm flap) ${ }^{16}$ in order to obtain a pedicle that is as long as possible and with the greatest skin surface possible.

The lateral arm flap is finer in its distal portion and it widens progressively. This has to be taken into account on adapting it to the surgical defect, and it can be an advantage for certain types of oropharyngeal defects. 14,17 The finer part can be used for the pharyngeal wall and the thicker part for the base of the tongue. The lateral arm flap is thicker than the radial forearm free flap, but it continues being a fine flap and one that is suitable for adapting to the shape of the mouth. When more volume is needed, the lateral arm flap can be raised with a portion of triceps muscle. ${ }^{18,19}$

The sectioning of the posterior cutaneous nerve of the forearm, that is produced in most cases when raising the flap, leads to a loss in sensitivity in the extension area of the forearm that is not normally appreciated by the patient and that reduces over time. ${ }^{2}$

There are many ways of obtaining a longer pedicle: by proximal dissection as described in the surgical technique, separating the triceps muscle or by placing the skin island more distally. ${ }^{14}$

Direct closure of the lateral arm flap can nearly always be carried out (if the width of the defect is less or equal to 6 $\mathrm{cm}$ ). In our case 2 patients required grafts. There is less of an aesthetic defect with the lateral arm flap than with the 
Los inconvenientes de este colgajo son: que el calibre de los vasos es pequeño, la disección y preparación de los vasos receptores debe ser cuidadosa: "cualquier vaso del lecho receptor puede ser necesario"; en pacientes obesos el colgajo puede ser excesivamente grueso; tiene un tamaño limitado, que resulta pequeño para grandes defectos; la longitud del pedículo puede ser en ocasiones limitada y se produce un área de hipoestesia-anestesia en el antebrazo.

\section{Conclusiones}

El colgajo lateral de brazo es útil para la reconstrucción de partes blandas intraorales y orofaríngeas, donde se precisa la aportación de un tejido suficientemente fino y adaptable a las paredes posterior y lateral faríngeas, y a la vez permita un adecuado aporte de volumen para la reconstrucción de la base de la lengua manteniendo la movilidad del segmento no extirpado.

\section{Bibliografía}

1. Song R, Song Y, Yu Y, Song Y. The upper arm free flap. Clin Plast Surg 1982;9:27-35.

2. Sullivan MJ, Carroll WR, Kuriloff DB. Lateral arm free flap in head and neck reconstruction. Arch Otolaryngol Head Neck Surg 1992;118:1095-101.

3. Yamamoto $\mathrm{Y}$, Minakawa $\mathrm{H}$, Yoshida $\mathrm{T}$, Igawa $\mathrm{H}$. Tongue reconstruction alter hemiglossectomy with the lateral arm free flan. J Reconstr Microsurg 1994;10:91-4.

4. Harpf C, Papp C, Ninkovic M, Anderl H, Hussl H. The lateral arm flap: review of 72 cases and technical refinements. J Reconstr Microsurg 1998;14:39-48.

5. Matloub HS, Larson DL, Kuhn JC, Yousif NJ, Sanger JR. Lateral arm free flap in oral cavity reconstruction: a functional evaluation. Head Neck 1989;11:205-11.

6. Alcalde J, Pastor MJ, Quesada JL, Martín E, Garcia-Tapia R. Reconstrucción de defectos orofaríngeos con colgajo lateral de brazo. Acta Otorrinolaringol Esp 2001;52:39-44.

7. Summers AN, Sanger JR, Matloub HS. Lateral arm fascial flap: microarterial anatomy and potential clinical applications. J Reconstr Microsurg 2000;16:279-86.

8. Moffett TR, Madison SA, Derr JW y cols. An extended approach for the vascular pedicle of the lateral arm free flap. Plast Reconstr Surg 1992;89:259-67.

9. Chen HC, el-Gammal TA. The lateral arm fascial free flap for resurfacing of hand and fingers. Plast Reconstr Surg 1997;99:454-9.

10. Shecker LR, Kleinert HE, Panel DP. Lateral arm composite tissue transfer to ipsilateral hand defects. J Hand Surg 1987;12:665-72.

11. Katsaros J, Tan E, Zoltie N, Barton M. Further experience with the lateral arm free flan. Plast Reconstr Surg 1991;87:902-10.

12. Rivet $D$, Buffet $M$, Martin $D$. The lateral arm flap: an anatomical study. J Reconstr Microsurg 1987;3:121-32.

13. Wenig BL. The lateral arm free flap for head and neck reconstruction. Otolaryngol Head Neck Surg 1993;109:116-9.

14. Gellrich NC, Schramm A, Hara I, Gutwald R, Duker J, Schmelzeisen R. Versatility and donor site morbidity of the lateral upper arm flap in intraoral reconstruction. Otolaryngol Head Neck Surg 2001;124:549-55.

15. Inoue T, Fujino T. An upper arm flan pedicled on the cephalic vein with arterial anastomosis for head and neck reconstruction. Br J Plast Surg 1986;39:451-3.

16. Brandt KE, Khouri RK. The lateral arm/proximal forearm flap. Plast Reconstr Surg 1993;92:1137-43.

17. Nahabedian MY, Deune EG, Manson P. Utility of the lateral arm flap in head and neck reconstruction. Ann Plast Surg 2001;46:501-505.

18. Gordon DJ, Small JO. The addition of muscle to the lateral arm and radial forearm flaps for wound coverage. Plast Reconstr Surg 1992;89:563-5.

19. Gosain AK, Matloub HS, Yousif NJ, Sanger JR. The composite lateral arm free flap: vascular relationship to triceps tendon and muscle. Ann Plast Surg 1992; 29:496-07. radial flap. ${ }^{3}$ The morbidity associated with the lateral flap donor site is very little, although the following have been described: pain in the epicondyle area, hypoesthesia of the skin proximal to the forearm, and a reduction in elbow movement. 20

The flap can be harvested by a second surgical team working simultaneously with the ablative team..$^{5}$ The preoperative examination consists only in an examination of the donor area. The vessels of the neck that adapt better to the caliber of the flap's vessels are the superior thyroid artery and the facial artery and veins of the thyro-linguo-facial trunk. ${ }^{5}$

This flap is as reliable as any other used for the reconstruction of the head and neck, and in general there is a success rate of $95 \% .4,6,14,17$

The lateral arm flap should be considered as a reconstructive option for oral mucosa surface defects. The advantages of this flap are: it offers a fine covering that is pliable and that adapts to the shape of the oral cavity, and good functional results for surface defects can be obtained. It possesses a consistent vascular pedicle that, in addition, is not essential for the vascularization of the distal extremity of the upper limb. It can be harvested as a neurotized flap, it is fast and easy to raise, and it can be harvested at the same time as the ablation is carried out. The patient can keep the same posture, it is of an intermediate thickness and, as a result, it is useful for defects of the oral cavity that require more volume than that provided by the radial forearm flap. There is little morbidity at the donor site and direct closure of the cutaneous defect can be carried out. On many occasions a very acceptable aesthetic result can be obtained in the donor site and, although the pedicle is short, there are surgical techniques for elongating it.

The disadvantages of this flap are: the small caliber of the vessels, and the dissection and preparation of the receptor vessels which should be done very carefully: "any vessel of the receptor bed can be necessary". In obese patients the flap may be too bulky. Its size is limited, and it can be small for large defects. The length of the pedicle can, on occasions, be limited and an area of hypoesthesia-anesthesia in the forearm will be produced.

\section{Conclusions}

The lateral arm flap is useful for reconstructing intraoral and oropharyngeal soft tissues, as tissue that is sufficiently fine and adaptable to the posterior and lateral pharyngeal walls is required. It also provides adequate volume when reconstructing the base of the tongue, and the mobility of the segment that has not been excised can be maintained. 